\title{
ESL Elementary Teachers' Use of Children's Picture Books to Initiate Explicit Instruction of Reading Comprehension Strategies
}

\author{
Al Tiyb S Al Khaiyali ${ }^{1}$ \\ ${ }^{1}$ School of Education, Department of Teaching and Learning, Washington State University, USA \\ Correspondence: Al Tiyb S Al Khaiyali, School of Education, Department of Teaching and Learning, \\ Washington State University, USA. E-mail: aalkhaiyali@wsu.edu
}

Received: October 11, 2013 Accepted: December 13, 2013 Online Published: January 6, 2014

doi:10.5539/elt.v7n2p90 URL: http://dx.doi.org/10.5539/elt.v7n2p90

\begin{abstract}
Reading comprehension instruction has been recognized as a key factor in developing any reading and literacy program. Therefore, many attempts were devoted to improve explicit comprehension strategy instruction at different school levels and fields including EFL and ESL. Despite these efforts, explicit comprehension instruction is still drought and far from satisfactory. Additionally, a great deal of teachers and educators are still struggling to find the appropriate ways to explicitly and effectively teach comprehension strategies. Consequently, the purpose of the present study was to explore the general perceptions and experiences of elementary English language teachers in using children's picture books to initiate explicit comprehension strategy instruction. In order to obtain naturalistic and in-depth understanding of participating teachers' perceptions, structured classroom observations were carried out for four weeks. Findings indicated that in about 718 minutes of instruction of both classrooms, 603 minutes were allotted for explicit comprehension strategy instruction. Despite some flaws in time management, the use of only one resource to collect data, and the focus on only comprehension strategy instruction, this study could contribute to the body of research of comprehension strategy instruction in language learning classrooms.
\end{abstract}

Keywords: reading comprehension, explicit strategy instruction, picture books

\section{Introduction}

Reading comprehension is an important component to any language and literacy program. It is considered "the essence of reading" (Durkin, 1993, p. 4), "the heart of reading" (Moore \& Hall, 2012, p. 24), and "the central driving force for reading" (Leu et al, 2007). Despite its importance, reading comprehension instruction remains neglected and deprived of appropriate attention, particularly in English language learning classrooms (Carrell, Pharis, \& Liberto, 1989). Over the last several years, however, a considerable numbers of researchers affirmed the value of reading comprehension strategies in enhancing reading comprehension (Fotovatian \& Shokrpour, 2007; Harvey \& Goudvis, 2007; Miller \& Perkins, 1990; Pressley, 2002). There was a consensus among researchers that reading comprehension strategies are defined as conscious practices and tactics that readers use to understand the text they read (Grabe, 2009; Paris, Wasik, \& Turner, 1996; Pressley, 2006). Also, Snow (2002, p. 11) emphasized that reading comprehension is "the process of simultaneously extracting and constructing meaning through interaction and involvement with writing language". Hence, cognition, metacognition, linguistics, motivation, engagement, interaction, and involvement were considered fundamental prerequisites of any reading comprehension process. Furthermore, most researchers suggested that reading comprehension strategy instruction should be implemented directly, explicitly, flexibility, and systematically (Duke \& Pearson, 2008). Nevertheless, there seems to be no consensus among a great deal of researchers of the type of materials that should help unskillful readers learn and use strategies. Specifically, research on the type of materials that might fit comprehension strategies instruction is still inconsistent and is rather described as "superficial" (Cohen \& Cowen, 2008, p. 176). Besides, many teachers do not know when, how, and why to teach text comprehension and are often not equipped enough to explicitly teach reading comprehension (Klingner, Vaughn, \& Boardman, 2007; Tovani, 2000). Consequently, the purpose of this study was to investigate teachers' experiences of using children's picture books to initiate explicit instructions of reading comprehension strategies of language learners at the elementary school levels. Working from this perspective, the following question was raised in order to guide the study's data collection, description, and analysis: 
To what extent did ESL teachers at fifth grade levels use explicit comprehension strategy instruction when they implemented some selected children's picture books in their instructional practices?

\section{Literature Review}

\subsection{Scarcity of Comprehension Strategy Instruction}

Since Durkin's (1978) study, attention was placed to learners' reading comprehension using various comprehension strategies. In her study, Durkin investigated the implementation of comprehension strategy instruction in core reading programs at some elementary schools in the State of Illinois. She discovered that only $5.3 \%$ of the teachers' overall reading instruction focused on comprehension strategy instruction. In the same vein, Miller and Perkins (1990) observed the amount of comprehension instruction in English language learning classrooms. Findings showed that comprehension instruction was very limited, and most classes' instruction was placed on vocabulary, syntax, and grammar. Eight years later, Pressley, Wharton-McDonald, Mistretta-Hampston, and Echevarria (1998) conducted an observational research to investigate the extent to which reading comprehension was explicitly taught in fourth and fifth grades. Observations were extended from November 1995 to May 1996 with a focus on teachers' use of explicit comprehension strategy instruction. Results showed that the amount of reading comprehension instruction increased slightly comparing to the findings of Durkin's observation. Moreover, the general comprehension teaching practice was based on showing how students could use comprehension strategies and not what these comprehension strategies actually mean. Recently, Ness (2011) observed the extent to which teachers from first to fifth grades use comprehension instruction in their language arts classrooms. Based on observing the teachers of the participating classroom, Ness found out that a total of $25 \%$ of the language arts teaching practices focused on explicit reading comprehension instruction. This score was the highest comparing to the findings of Durkin, Miller, Perkins, and Pressley et al. Furthermore, remarkable research studies were implemented Ahmadi, Ismail, and Abdullah (2013), Hou (2013), and Ghavamnia, Ketabi, and Tavakoli (2013) to track comprehension strategy instruction in language learning classrooms. The overall results of these studies showed that comprehension strategy instruction developed gradually comparing to findings in previous research, nevertheless, it is still drought and far from satisfactory (Pressley, 2006; Williams, 2002).

\subsection{The Need to Develop Comprehension Strategies Instruction}

Traditionally, teaching reading comprehension was based only on explaining how learners can decode words (Pressley \& Wharton-McDonald, 2006) and the text memorization (Frederiksen, 1972; Mandler \& Johnson, 1977). Recently, the concept of teaching reading comprehension was evolved and dramatic changes were proposed to explain the process of reading comprehension instruction. One of the leading assumptions in this regard advocated the implementation of strategies used by skillful readers to teach and improve the reading comprehension abilities of poor or less skillful readers (Brown, Armbruster, \& Barker, 1986; Moats, 2005). Therefore, many researchers realized that there were different types of strategies that strategic readers use when they want to make sense of what they read. These strategies have been classified and termed differently among researchers. For example, some strategies were called, "the word-level" or "text-level" (Barnett, 1988, p. 150), "global" or "local" (Barnard, Harley, Graziella, \& Tom, 1980, pp. 405-410), and recently rephrased "cognitive" and "metacognitive" (Alavi \& Ganjabi, 2008, p. 208; Grabe, 2009, p. 222; Yang, 2006, p. 315). Metacognitive strategies are related to readers' self-evaluation and thinking about their learning process (O'Malley et al., 1985). On the other hand, cognitive strategies are related to tasks, processes, and efforts that are applied to make sense of the reading materials (Yang, 2006). Strategic readers rely on the integration of cognitive and metacognitive strategies in order to make sense of what they read (Yang, 2006). Based on these assumptions, a great deal of researchers emphasized the integration of cognitive and metacognitive strategies to better improve the comprehension abilities of readers (Neupert \& McDonal-Miszczak, 2004). Based on these perspectives, Janzen and Stoller (1998) infused all these strategies into the following list: identifying a purpose for reading, checking prediction, finding an answer to a question, connecting text to the prior knowledge, previewing, asking questions, summarizing, connecting one part of the text to another, and recognizing text structure. Palincsar (1982) used predicting, questioning, seeking clarification, and summarizing when she introduced the reciprocal teaching approach. Keene and Zimmerman (1997) added prior knowledge or what has come to be called schema, being metacognitive, making connections, inferring, asking questions, determining big ideas, evoking images, monitoring comprehension, fixing-up strategies, and synthesizing. In a similar vein, Harvey and Goudvis (2007, pp. 22-31) used the same strategies with slight modification in terminologies. They came up with a comprehension strategy list that contained activating background knowledge, making connections, questioning, making inferences, visualizing, determining importance, summarizing, synthesizing, and monitoring. Despite their vast variations, there was a consensus among many researchers and theorists that, "the super six" 
comprehension strategies were often used by skillful readers and were suggested to be taught to incompetent or less skillful readers (Oczkus, 2004). These strategies included building background/making connections, predicting/inferring, questioning, monitoring, summarizing, and evaluating. In addition, reading comprehension strategy instruction was considered as an important indicator in developing the reading comprehension achievements of many native and English language learners who were considered poor comprehenders (Duke \& Pearson, 2002; National Reading Panel, 2000; Fisher \& Frey, 2008; Tompkins, 2006). For instance, Boulware-Gooden, Carreker, Thornhill, and Joshi (2007) investigated the impact of systematic and direct instruction of multiple cognitive strategies on vocabulary and reading comprehension development. Participants were 119 students from six third-grade classrooms who were native speakers of English. Results indicated that direct and systematic instructions of cognitive comprehension strategies contributed significantly to increase the learners' scores of expository text comprehension and vocabulary growth. In the same vein, the direct impact of comprehension strategy instruction was reported by a considerable numbers of studies, particularly in English as a first language learning context (Harvey \& Goudvis, 2007; Pressley, 2002). Despite the significance of comprehension strategies in developing the learners' comprehension performance, instruction in comprehension strategies is still considered dearth and insufficient, particularly in language-learning classrooms (Pressley, 2006; Vaughn, Levy, Coleman, \& Bos, 2002). The lack of appropriate material resources to initiate the teachers' instruction of comprehension strategies was essentially considered one of the major factors that contributed to this issue (Cohen \& Cowen, 2008; Cohen, Weaver, \& Li, 1996). Therefore, the use of authentic, interesting and easy-reading materials such as children's picture book could be fundamental to fill this gap.

\subsection{Rationale of Using Children's Picture Book in Comprehension Strategy Instruction}

There has been a general agreement among the experts of children's literature that a picture book is considered a genre of children's literature in which illustrations, design and words usually tell the story (Culham \& Coutu, 2008). Culham and Coutu (2008) defined picture books as the meaningful integration of illustrations, words, and design. In picture books, illustrations and words usually complete each other, and readers often understand the story by looking at the illustrations, the words, or the illustrations and the words at the same time (Jalongo, 2004). Throughout its long history, children's picture books occupied a special place in education (Cho \& Kim, 1999; Goodwin, 2008). This is because picture books cover wide areas of topics, contain delightful words, comprehensible illustrations, unique styles, interesting cultural variations, and information density (Nodelman \& Reimer, 2003). These features were proven to have important effects on facilitating teaching and learning any piece of information from picture books (Heuvel-Panhuizen, Boogaard, \& Doig, 2009). For example, illustrations and drawings in some picture books were considered effective and motivational (Columba, Kim, \& Moe, 2009; Paivio, 1971). Mitchell (2002, p. 71) combined most picture books' features and definitions in her explanation to the meaning of picture books. She stated that "picture books" evokes images of brightly colored, beautifully illustrated books that beg to be read. No matter what our age, most of us still enjoy reading them because of their vibrant pictures, rich and evocative language, and poignant and meaningful themes. Picture books speak to us in the same way photographs do. They touch our emotions, delight our senses, appeal to our whimsy, and bring back memories of our childhood. Picture books invite us to curl up and read them. Therefore, these features could help readers remember and retain information. All the distinctive characteristics and variations of picture books may open new vistas to use them to teach reading comprehension strategies explicitly in language learning classrooms. In addition, picture books contain different genres and cover various types of topics. The variations and increasing numbers of picture books could make the selection of the appropriate picture books a difficult and challenging task. However, for the purpose of this study and as general standards for the selection of picture books, the following criteria were considered: picture books that are to be used to explicitly teach comprehension strategies should fulfill the following: (1) meet the needs of the learners, (2) meet the learners' teaching objectives, (3) meet the learners' cultural needs, (4) comprehensible, (5) easy-to-read, (6) well-illustrated, (7) interesting, (8) short and not time consuming, and (9) authentic; relevant to the learners' world and real life (Goodwin, 2008; Jalongo, 2004; Lado, 2012).

\section{Theoretical Foundations}

Basically, this study was built on several theories and propositional approaches, however, the dual coding theory (Paivio, 1971), strategies-base instruction (Cohen, Weaver, \& Li, 1996), and schema theory (Anderson \& Pearson, 1984) were fundamental in constructing the theoretical blocks of this study. The dual coding theory was built on the assumption that pictures and words are considered two interconnected codes that contribute covertly and/or overtly to sustain the learner's memory. In his explanation of dual-coding theory, Paivio (1971) provided important evidence about the role of illustrations and pictures (the important characteristic feature of picture books) in facilitating readers' understanding and comprehension of the text. According to Paivio (Sadoski \& 
Paivio, 2013), meaningful illustrations are very essential in promoting memory for processing the factual information in any text. On the other hand, strategies-based instruction was built on two basic elements: (1) teaching learners explicitly how, when, and why strategies are used (scaffolding the students' declarative, procedural, and conditional knowledge) and (2) integrating strategies into class materials and using strategies in the general language tasks. Finally, schema theory was built on the assumption that learners' knowledge and understanding of any topic is essentially related to their previous knowledge of that topic. Schema theory emphasized the need to build learners' prior knowledge to implement the right strategy and hence understand the reading piece. Understanding the components of schema theory is an essential part to comprehension strategy instruction because most strategies are built on learners' prior knowledge or schemata (Anderson \& Pearson, 1984). For example, learners may not be able to employ connection strategy if they have no prior knowledge of what they read.

\section{Methodology}

In order to obtain an in-depth understanding of participants' experiences and perceptions as they respond to the use of picture books in explicit comprehension strategy instruction, this study was built on the paradigm of qualitative inquiry (Bernard \& Ryan, 2010; Merriam, 2009).

\subsection{Design}

According to Given (2008), a qualitative exploratory design can be used when knowledge about the research group(s), activity(ies), situation(s), or process(es) is very little or not well defined. Therefore, this study was based on qualitative-exploratory design because it focused on the experiences and perceptions of groups (Arabian ESL teachers in the fifth grade) who used new materials (children's picture books) to lead classroom instruction using new process (explicit comprehension strategy instruction) for their first time in their language teaching programs. Furthermore, Churchill and Iacobucci (2010, pp. 60-61) provided a rationale for selecting exploratory design to qualitatively investigate a specific problem. According to them, exploratory research designs "are characterized by flexibility with respect to the research methods used...investigators frequently change the research procedure as the vaguely defined initial problem is transformed into one with more precise meaning...exploratory research is appropriate for any problem about which little is known...exploratory research is the foundation for a good study". Consequently, the exploratory design could contribute to rigorous and conclusive findings for future research by providing an in-depth understanding of the use of children's picture books in teaching reading comprehension strategies in minority ESL classrooms.

\subsection{Participants}

Two fifth grade English languages teachers from the Middle East participated in this study. Jamila (pseudonym) a 31-year-old woman and Ahmad (pseudonym) a 33-year-old man. Both teachers speak Arabic as their native language and were enrolled in the TESOL graduate program in University of Colorado at Boulder in the U.S. since fall 2011. Both teachers were part time instructors in this school and used to teach two different fifth grade classes for three hours per week.

\subsection{Setting}

The study took place at an Arabic Bilingual School in Colorado, Denver. Two fifth grade classes were involved in this study, and each class has 22 students. The average of the students' age was 12-14 years at the beginning of the study. The students were mainly Arabic speakers who were originally from three countries Egypt, Libya, and Morocco. All the students were taught English as a second language. English language was taught four times per week for each class, and each class was receiving 45 minutes comprehension instruction in the regular English classes. The study took place in the summer semester of 2012 after obtaining an IRB and the administrative approvals to conduct the study.

\subsection{Materials}

Four picture books were selected to be used to comprehension strategy instruction in this study. The selected picture books were The Giving Tree by Silverstein (1964); Polar Bear, Polar Bear, What do You Hear by Martin and Carle (1997); Hairy, Scary, Ordinary: What is an Adjective? by Cleary (2001); and Big Blue Whole by Davies (2001). Table 1 shows detailed description of the selected picture books. 
Table 1. Details of the selected picture books

\begin{tabular}{|c|c|c|c|c|c|}
\hline Title & Author(s) & Illustrator(s) & $\begin{array}{l}\text { Publication } \\
\text { Year }\end{array}$ & Publishers & Synopsis \\
\hline $\begin{array}{l}\text { The Giving } \\
\text { Tree }\end{array}$ & Silverstein & Silverstein & 1964 & $\begin{array}{l}\text { Harper \& } \\
\text { Row, NY }\end{array}$ & $\begin{array}{l}\text { A boy and a tree love each other. } \\
\text { Every day the boy comes to the tree, } \\
\text { plays with her, climbs her, and } \\
\text { sometimes asks her to give him } \\
\text { something. The tree loves the boy } \\
\text { and attempts to do anything to make } \\
\text { him happy. One day, the boy asks the } \\
\text { tree for money, the tree gives him all } \\
\text { what she has. Then, the boy grows up } \\
\text { and comes back again asking for } \\
\text { more money. The tree tells the boy } \\
\text { "the old man" that she gives. }\end{array}$ \\
\hline $\begin{array}{l}\text { Polar Bear, } \\
\text { Polar Bear, } \\
\text { What do } \\
\text { You Hear }\end{array}$ & $\begin{array}{l}\text { Bill Martin } \\
\text { \& Eric } \\
\text { Carle }\end{array}$ & $\begin{array}{l}\text { Bill Martin } \\
\text { Eric Carle }\end{array}$ & 1997 & $\begin{array}{l}\text { Henry Holt } \\
\& \text { Co, NY }\end{array}$ & $\begin{array}{l}\text { This story rhythmically illustrates the } \\
\text { sounds of some zoo animals. The } \\
\text { readers can learn about the sounds of } \\
\text { animals usually kept in zoos such as } \\
\text { bears, snakes, lions, and } \\
\text { hippopotamuses. A DVD comes with } \\
\text { this story to demonstrate these } \\
\text { sounds }\end{array}$ \\
\hline $\begin{array}{l}\text { Hairy, } \\
\text { Scary, } \\
\text { Ordinary: } \\
\text { What is an } \\
\text { Adjective? }\end{array}$ & $\begin{array}{l}\text { Brain } \\
\text { Cleary }\end{array}$ & $\begin{array}{l}\text { Jenya } \\
\text { Prosmitsky }\end{array}$ & 2001 & $\begin{array}{l}\text { Carolrhoda } \\
\text { Books, } \\
\text { Minneapolis }\end{array}$ & $\begin{array}{l}\text { This story is about some cat friends } \\
\text { communicate using rhythmic } \\
\text { adjectives. These cats play with } \\
\text { adjectives to provide a } \\
\text { straightforward explanation of how } \\
\text { readers can use adjectives. The story } \\
\text { starts with a definition of the } \\
\text { adjective, and then it provides a list } \\
\text { of examples of how adjectives are } \\
\text { used. }\end{array}$ \\
\hline $\begin{array}{l}\text { Big Blue } \\
\text { Whole }\end{array}$ & $\begin{array}{l}\text { Nicola } \\
\text { Davies }\end{array}$ & Nick Maland & 2001 & $\begin{array}{l}\text { Candlewick } \\
\text { Press MA }\end{array}$ & $\begin{array}{l}\text { The story describes the basic facts } \\
\text { about the blue whale, how big it is } \\
\text { and where does it live? }\end{array}$ \\
\hline
\end{tabular}

These picture books were selected because they met criteria of using picture books in comprehension strategies instruction listed earlier. In addition, standardized English language materials were used occasionally and after completing instruction using the selected picture books. Some sections were used from the standardized English materials (the English language textbook) to reaffirm some strategies that were taught using the picture books.

\subsection{Procedure}

Before collecting data for this study, both teachers received a short professional development program. The program aimed to introduce the selected picture books to the teachers, identify reading comprehension strategies, and show some models and instructional practices to explicitly teach these strategies. During the training program, both teachers learned about the picture books that they would use and how each picture book could be used to explicitly teach reading comprehension strategies. Specifically, I introduced some basic comprehension strategies (word decoding, activating prior knowledge, summarization, questioning, predicting, determining big ideas, visualizing, synthesizing, inferring, monitoring, semantic/story mapping, comparing, and contrasting) to both participating teachers, defined these strategies, and gave some examples to each about how and when they can be used. The strategies overview was accompanied with different teaching models that were borrowed from previous research (Almasi, 2003). Moreover, I introduced some classroom instructions, activities, and tasks that might help teachers engage the class and teach comprehension strategies (e.g., K.W.L chart, read aloud, think aloud, literature circles, reciprocal teaching, and response to literature). These instructions, activities, and tasks were also built on previous research studies (Almasi, 2003; Snow, 2002; Tovani, 2000). These instructional methods were defined and exemplified, and teachers were shown when, where, and how to use them. Teachers 
were given the freedom to decide whatever approach to use and whatever strategy to teach based on their lesson plan and purpose. Strategies were recommended to be taught in isolation and then multiple strategies instruction was also emphasized. Finally, teachers were recommended to organize their lesson plan and were provided many suggestions to use whenever possible. Specifically, teachers were asked to support and encourage students as possible as they could, provide a space for students to work individually and in teams, use varieties of instructions, activities and tasks, define, model, and exemplify concepts whenever possible. In their classrooms, teachers introduced the strategies to their students by defining them, explaining when, where and why they should be learned, and modeling these strategies step-by-step using think aloud. Each strategy was defined, explained, modeled independently, and then strategies were combined based on the needs and objectives of the lesson. Afterwards, both teachers released responsibility by using guided practice (encouraging students to practice and use the learned strategy). The teachers' instructions were observed and video-recorded. Finally, students were assessed to monitor their reading comprehension general progression.

\subsection{Data Collection}

The study was based on structured classroom observations as a major means for data collection. The classroom observation processes were structured because they were based on different instructional techniques and routines conducted and designed before the beginning of this study. These techniques were informed by a pilot study implemented a year ahead of this study. More specifically, the techniques dealt with general practices that determined the frequency and the amount of comprehension strategy instruction (Ness, 2011; Pressley, 2006). The observations lasted for four weeks, and there was a total of 720 minutes for both classes. The observation practices shed light on the teachers' instructions of what the strategy was, when it should be used, and how the strategy should be used. Also, the techniques and practices that teachers used to connect the explicit teaching of comprehension strategies and their use of picture books were observed. The overall purpose of the teachers' observation was to elicit a general naturalistic understanding of the teachers' experiences of using children's picture books to explicitly teach reading comprehension strategies (Maxwell, 2013; Merriam, 2009). Both classes were observed equally during the English language instruction classes for four weeks. To provide an in-depth and thick sense of the collected observation notes, all the observations were video-recorded (Heath, Hindmarsh, \& Luff, 2010).

\subsection{Data Analysis}

All the observation notes were first collected, organized, member-checked, and then coded during and after the fieldwork. The general instructional processes of what, when, and how strategies were used, and the applicability of children's picture books in the instruction processes were used to guide the categories of coding procedures. Teachers' behaviors, routines, and reactions of using these practices for about 40 -seconds or more were coded using ATLAS.ti 7 (2013). On the other hand, the practices that contained none of the previous instructions or behaviors were marked as non-instructional codes (Miles, Huberman, \& Saldana, 2014). Table 2 shows the major instructional and noninstructional codes of this study. After the coding procedures, all the collected data were "condensed", "displayed", and finally "verified" and discussed in its final phase of the analysis (Miles, Huberman, \& Saldana, 2014, pp. 12-13).

Table 2. Average total of instructional and non-instructional comprehension practices

\begin{tabular}{llll}
\hline $\begin{array}{l}\text { Explicit comprehension } \\
\text { strategy instructional codes }\end{array}$ & $\begin{array}{l}\text { Average of } \\
\text { instructional } \\
\text { practices }\end{array}$ & $\begin{array}{l}\text { None comprehension } \\
\text { instructional codes }\end{array}$ & $\begin{array}{l}\text { Average of } \\
\text { noninstructional } \\
\text { practices }\end{array}$ \\
\hline $\begin{array}{l}\text { Building background/making } \\
\text { connections }\end{array}$ & $81 \%$ & Translation & $30 \%$ \\
Predicting/inferring & $89 \%$ & Writing instructions & $10 \%$ \\
Questioning & $89 \%$ & Read-aloud & $17 \%$ \\
Monitoring & $71 \%$ & Silent reading & $14.1 \%$ \\
Summarizing & $83 \%$ & Group work assignments & $16 \%$ \\
Evaluating & $81 \%$ & Non-instruction & $29.5 \%$ \\
\hline Total & $82.3 \%$ & & $17.7 \%$ \\
\hline
\end{tabular}




\section{Findings}

It was spectacularly that comprehension instruction occurred 603 (300.15 per teacher) minutes out of 718 minutes (359 minutes per teacher), the total time of classroom instructions in both classes. Specifically, explicit comprehension strategy instruction made up $82.3 \%$ of the classroom total instructions. One potential explanation for the dramatic increase of comprehension strategy instruction in these classrooms was that both teachers devoted their entire teaching program to use only the selected picture books and to teach only the assigned reading comprehension strategies. In addition, the participating teachers focused on delivering explicit comprehension strategy instruction using picture books and they did not measure the students' reading comprehension achievements. This was because measuring the students' comprehension strategy achievements was beyond the scope of this study. Figure (1) shows the amount of instruction spent in each comprehension strategy when different picture books were used.

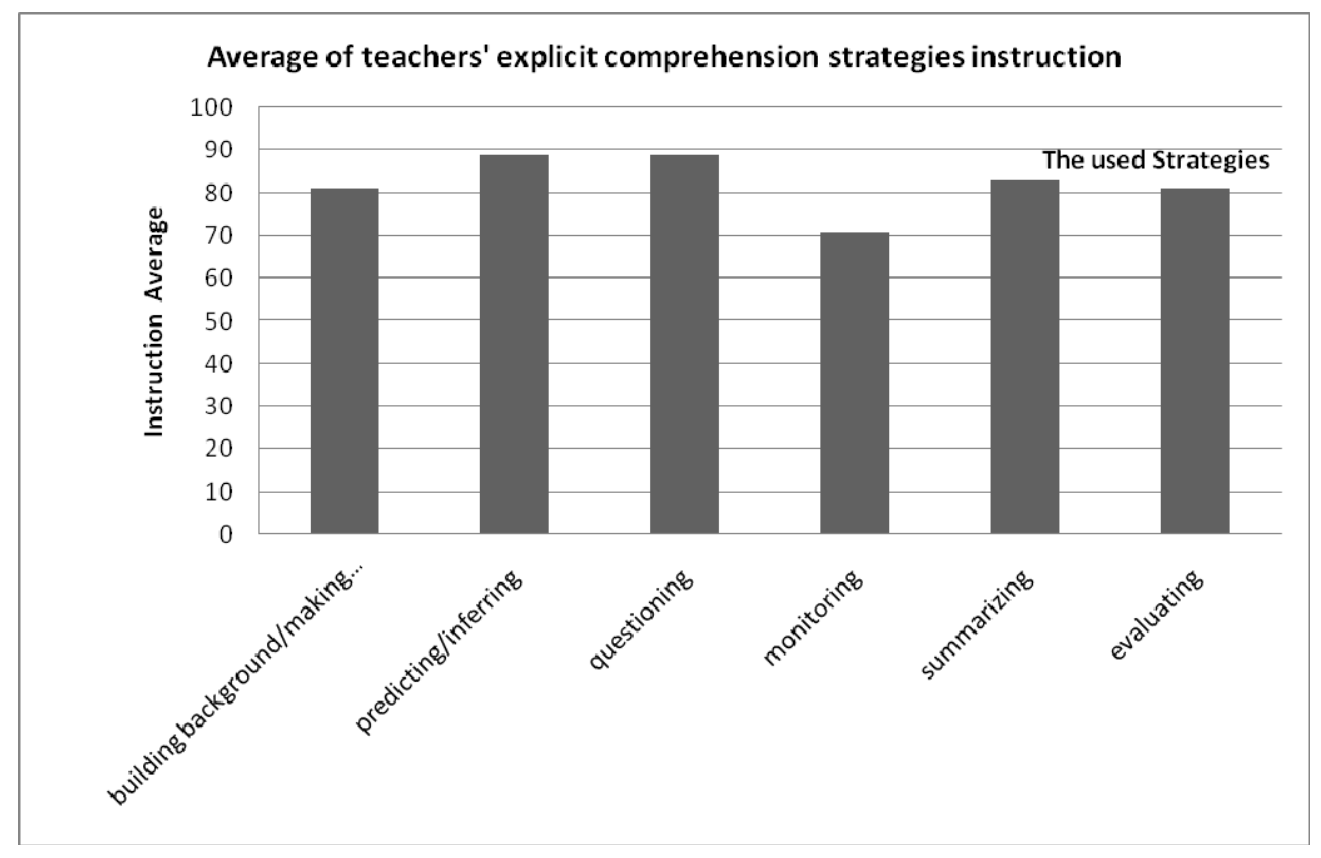

Figure 1. The average of comprehension strategy instruction

Moreover, the codes of comprehension instruction strategy practices of the teachers showed that both teachers used picture books to model each comprehension strategy before, during, and after they finish reading the stories. This could essentially be due to the fact that teachers were focusing on teaching the super six strategies and using only the selected picture books during the time of the study. The students' reactions in both classes varied but not precisely observed since the purpose of this study was only to focus on the instructions implemented by the teachers.

\section{Discussion}

The purpose of this study was to explore the perceptions and experiences of EFL teachers at the elementary grade levels of using children's picture books to initiate explicit instructions to some reading comprehension strategies. The study was based on the assumption that there was a decline in the overall reading comprehension achievements in many EFL and ESL classrooms. Specifically, the assumption was related to the dearth of comprehension instruction in these classroom settings (Fotovatian \& Shokrpour, 2007; Miller \& Perkins, 1990). It was believed that a better understanding of the teachers' perceptions in using children's picture books to explicitly initiate comprehension strategy instruction could help in developing good models to improve explicit reading comprehension strategy instruction in those classrooms. Therefore, this study used qualitative exploratory inquiry in order to provide holistic and naturalistic views for future experimental research (Maxwell, 2013). Semi-structured observations were used as primary resources to collect data. Meanwhile, all data were coded, analyzed, and organized according to themes in order to meet the basic categorical findings. Teachers' overall behaviors and reactions were considered essential to this study because exploring the pedagogical aspects of explicit reading comprehension instruction using picture books was one of its major goals. Hence, the 
following themes emerged from the classroom observation notes were emerged and discussed further bellow: (a) teachers' reactions of using picture books in EFL classrooms and (b) explicit instruction of comprehension strategies in EFL classrooms:

\subsection{Teachers' Reactions of Using Picture Books in EFL Classrooms}

In the professional development program, the seventh and eighth grade teachers in both classrooms received general overview of picture books, what are they, how, where, and when they could be used to teach reading comprehension strategies in language learning classrooms. Also, both teachers were trained to use picture books to explicitly teach some reading comprehension strategies. Both teachers were involved in the professional training program because they showed that they did not use explicit comprehension strategy instruction in their classrooms (Al Khaiyali, 2013). After their teaching practices, both teachers reacted positively to the use of some major characteristics of picture books in their classes. Findings indicated that both teachers showed that teaching with picture books was more interesting and fun than teaching with the standardized English language materials (textbooks). In addition, the findings of the classroom observations reconfirmed the positive perception of both teachers in using picture books. Specifically, findings from classroom observations showed that both teachers started introducing the new lesson by presenting a new strategy using a picture book and then they taught the same strategy using a section in the standardized materials, and this was over the whole period of the study.

\subsection{Explicit Instruction of Comprehension Strategies in EFL Classrooms}

Providing explicit comprehension strategy instruction was a fundamental requirement to the teaching of comprehension strategy using picture books. Therefore, both teachers tried hardly to put the ideas of explicit instruction that they learned in the professional development program into practice. This is because both teachers were used to teach in a completely different style and using a completely different teaching philosophy (drill and practice, memorization, traditional, grammar translation). Both teachers started using a new way of teaching that they had only one week to practice. Generally, both teachers' explicit instruction was based on introducing any new words in the assigned reading, reading the assigned text aloud, overviewing the assigned reading, providing students opportunities to read the assigned reading aloud and talk about it, presenting a new strategy using the same reading, defining, modeling using think-aloud, encouraging students to practice the strategy using the assigned reading, and providing feedback to scaffold the students' understanding of the assigned reading and strategy. After finishing presenting strategies in isolation, multiple strategies instruction which was based on teaching more than one relevant strategy was presented. Figure 2 summarizes the major components of explicit comprehension strategy instruction that were filtered from different teachers' data using ATLAS.ti7.

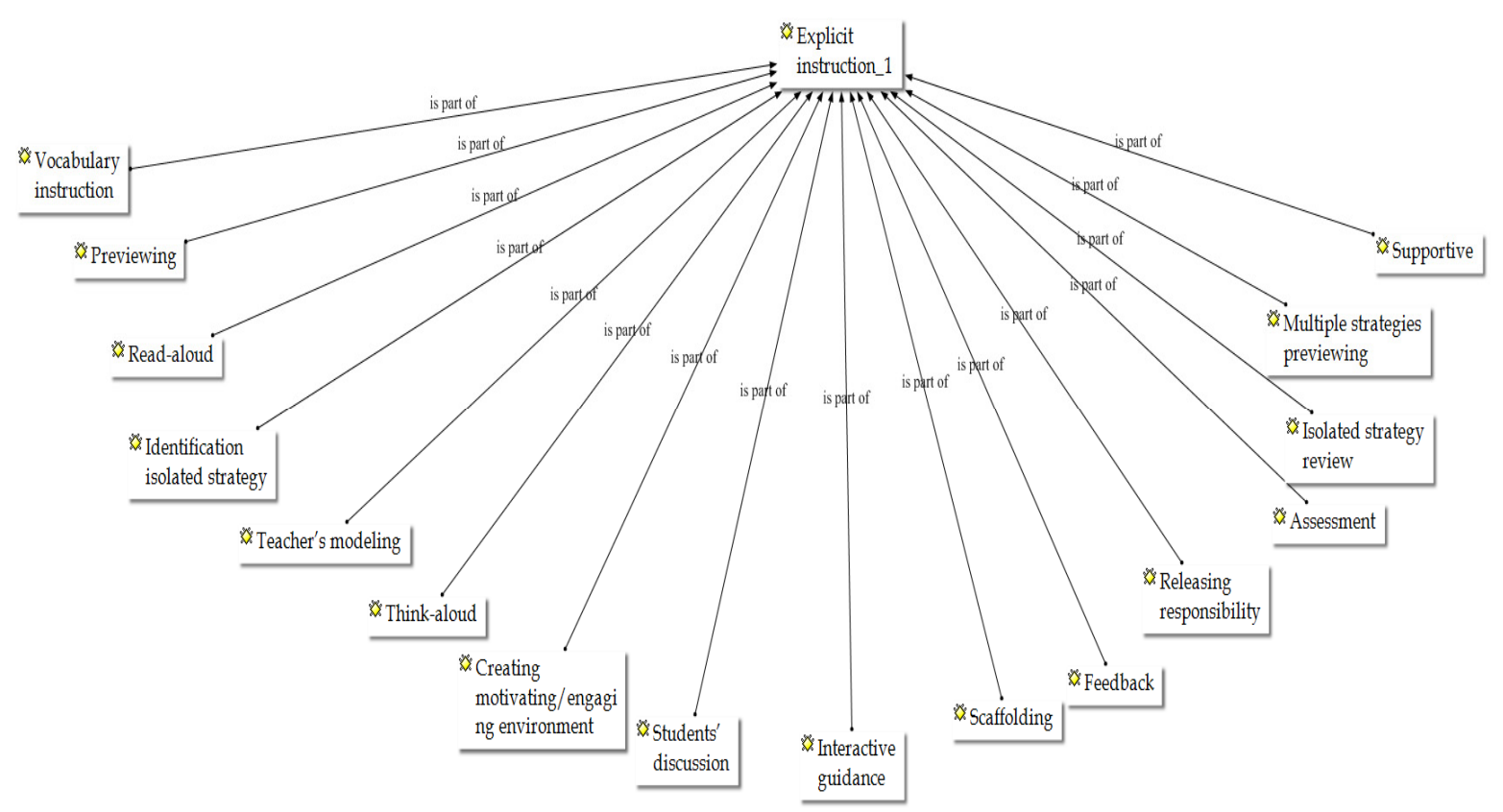

Figure 2. Components of explicit comprehension strategy instruction 
As demonstrated in Figure 2, both teachers started regularly introducing any new reading by presenting the new words, introducing the assigned readings, presenting the target strategy, and ending up with assessing and supporting the students' understanding of the reading(s). Despite the consistency in the teachers' instructional elements, both teachers emphasized that they preferred implementing some steps over others and sometimes not using some steps in their instruction. Hence, all these gear-shits were based on the students' needs and the class objectives.

\section{Conclusion}

Comprehension strategy instruction was considered an important but neglected practice in most language learning classrooms. More research studies confirmed that comprehension strategy instruction is not receiving the appropriate attention (Durkin, 1978; Pressley, Wharton-McDonald, Mistretta-Hampston, \& Echevarria, 1998; Ness, 2011), partly because of the deficiency of explicit comprehension strategy instruction and the lack of appropriate materials to prepare learners to use comprehension strategies appropriately (Pressley, Wharton-McDonald, Mistretta-Hampston, \& Echevarria, 1998). Therefore, the purpose of this study was to observe the use of children's picture books to initiate explicit instruction of some reading comprehension strategies. The characteristic features of picture books such as well-illustrated, contain high frequency words, easy-to-read, interesting, comprehensible, thematic, authentic, motivating, engaging, and short could make them suitable materials to initiate explicit comprehension strategies instruction. Consequently, picture books were used for four weeks to explicitly teach comprehension strategies to elementary English learning students. In order to find the amount of comprehension strategy instruction after the implementation of some selected picture books in the assigned classes, structured observations were used. Findings from the fifth grade classroom observations indicated that explicit comprehension strategy instruction was higher than other instructional and noninstructional practices. More importantly, findings showed that children's picture books could contribute to resolve some of the major issues in comprehension strategies instruction in language learning classrooms, particularly if they were precisely selected and appropriately used.

\section{Limitations}

As any qualitative inquiry, this study contained a very small sample size (only two teachers) that made it limited to generalizability. Moreover, the use of only one resource of data collection (structured observations) and member-checks could not contribute to fully triangulate the data for this study and hence limited its trustworthiness. Another potential limitation was related to the time allotted to the teachers' training and classrooms instruction. Teachers had only one month for professional development training and classrooms comprehension strategies instruction which could not be sufficient for rigours instructional practices. Also, it might not be appropriate to establish absolute judgments of comprehension strategies instruction in elementary classrooms. Moreover, teachers were only trained to teach specific comprehension strategies using specific picture books (only four picture books) that could affect the dependability of the study's results, particularly in regular English language learning classrooms.

\section{Implications for Teachers}

Despite its limitations, there were several teaching and pedagogical implications of this study. First, providing explicit instruction using authentic and easy-reading materials such as children's picture books may contribute to better improvement of ESL students' reading comprehension achievements. This is because the overall findings of this study showed that fifth grade teachers reacted positively towards the use of picture books, participated actively, and showed some interest to teach using picture books. Thus, the use of well-selected picture books to initiate explicit reading comprehension instruction could bridge the gaps that might exist in the English language materials, especially when teaching reading comprehension. In other words, picture books could be used to customize the English learning materials to meet the needs of explicit reading comprehension instruction in these classrooms. Second, ESL teachers could benefit from using an explicit instructional program that includes using preliminary materials, modeling using think-aloud, reciprocal instruction, scaffolding, providing feedback, and releasing responsibility in consolidating reading comprehension instruction at any grade levels. The findings of this study emphasized the fact that reading comprehension instruction should be explicit and flexible. Hence, teachers and students should jointly transact with the text in order to understand it. In other words, teachers' mission is not to mechanically teach comprehension strategy, rather teachers should understand that reading comprehension is a sophisticated process that entails teacher-student collaboration. The fundamental principles of explicit and flexible comprehension strategy instruction were consistent to Harris and Pressley's (1991, p. 403) which were succinctly elaborated in the following quote, "Good strategy instruction is not rote. Students are not just memorizing steps and mechanically executing them; strategy instructors are not drill sergeants. Rather, good 
strategy instruction entails making students aware of purposes of strategies, how and why they work, and when and where they can be used. Students are given extensive practice in the context of ongoing school instruction, practice which produces a personalized mastery of the method. Further, students are actively involved in the evaluation, modification, and construction of strategies. Teachers do not give orders, but rather model, discuss, explain, and reexplain, and in the process of doing so, teachers' understandings of strategies and their students change. Teachers and students are constructing important new knowledge during strategy instruction". Finally, this study might contribute to the body of research of comprehension strategy instruction in elementary language learning classrooms. In addition, the results show that picture books could provide elementary English language teachers interesting and comprehensible means to explicitly teach reading comprehension strategies (children's picture books).

\section{Recommendations for Future Research}

One of the major goals of this study was to provide a research ground through which further experimental studies could successfully be implemented, particularly in ESL contexts. Research on comprehension strategy instruction was very limited in these educational environments. Therefore, qualitative exploratory investigation was conducted. Specifically, the implementation of experimental based-research in these environments is highly emphasized since providing precise experimental measurements and details were beyond the scope of this study. Hence, more experimental research should be done in the area of explicit comprehension instruction using picture books with larger sample size and other grade levels. In addition, this study placed heavy attention on the use of children's picture books to initiate explicit instruction of reading comprehension strategies. In this study, I did not look at the difference between the uses of two different types of materials in comprehension instruction. More research might be needed to investigate the differences in using various genres of materials in reading comprehension instruction. Finally, a number of specific research question emerged from the overall findings of this study that might help to guide any future research inquiry including the following: (1) what is the actual impact of the implementation of children's picture books to developing reading comprehension abilities of EFL students? And (2) are there any preferences in using reading comprehension strategies to develop understanding the reading text? If so, what strategies could have more influence on students' actual understanding of the text? Another question that guides me further into relatively unexplored terrain related to 3. Whether the use of children's picture books will impact learning some strategies and skills over others? Specifically, how about the performance of EFL learners in other language skills, are there any changes in the EFL students' performance in other language skills since the instruction emphasized reading comprehension?

\section{References}

Ahmadi, M., Ismail, H., \& Abdullah, M. (2013). The importance of metacognitive reading strategy awareness in reading comprehension. English Language Teaching, 6(10), 235-244. http://dx.doi.org/10.5539/elt.v6n10p235

Alavi, S., \& Ganjabi, M. (2008). The relationship between metacognitive and cognitive strategies and reading comprehension in second language learning. In M. Shaughnessy, M. C. Veenman, \& Kleyn-Kennedy (Eds.), Meta-cognition: A recent review of research, theory and perspectives (pp. 207-220). New York, NY: Nova Science Publishers, Inc.

Al Khaiyali, A. (2013). Exploring teachers' use of comprehension instruction in EFL classrooms. WAESOL World Quarterly, 1(1), 8-10.

Almasi, J. (2003). Teaching strategic processes in reading. New York, NY: The Guilford Press.

Anderson, R. C., \& Pearson, P. D. (1984). A schema-thematic view of basic processes in reading comprehension. In P. D. Pearson, R. Barr, M. L. Kamil, \& P. Mosenthal (Eds.), Handbook of reading research. New York: Longman.

Barnard, R., Harley, B., Graziella, P., \& Tom, R. (1980). Reading strategies. In C. Guiseppina (Ed.), Reading a foreign language (pp. 400-415). Milan: Franco Angeli.

Barnett, M. (1988). Reading through context: How real and perceived strategy use affects L2 comprehension. Modern Language Journal, 72(2), 150-162. http://dx.doi.org/10.1111/j.1540-4781.1988.tb04177.x

Bernard, R., \& Ryan, G. (2010). Analyzing qualitative data. London, UK: SAGE Publications, Inc.

Boulware-Gooden, R., Carreler, S., Thornhill, A., \& Joshi, R. M. (2007). Instruction of metacognitive strategies enhances reading comprehension and vocabulary achievement in third graders. The Reading Teacher, 61(1), 70-77. http://dx.doi.org/10.1598/RT.61.1.7 
Brown, A. L., Armbruster, B. B., \& Baker, L. (1986). The role of Metacognition in reading and studying. In J. Orasanu (Ed.), Reading comprehension: From research to practice (pp. 49-75). Hillsdale, NJ: Lawrence Erlbaum Associates Publishers.

Carrell, P., Pharis, B. G., \& Liberto, J. C. (1989). Metacognitive strategy training for ESL reading. TESOL Quarterly, 23(4), 647-678. http://dx.doi.org/10.2307/3587536

Cho, B., \& Kim, J. (1999). The improvement of children's creativity through Korean picture books. Childhood Education, 75(6), 337-341. http://dx.doi.org/10.1080/00094056.1999.10522053

Churchill, J. R., \& Iacobucci, D. (2010). Marketing research: Methodological foundations (10th ed.). Mason, OH: South-Western Cengage Learning.

Cohen, A. D., Weaver, S. J., \& Li. (1996). The impact of strategies-based instruction on speaking a foreign language. Research Report. Minneapolis: Center for Advanced Research on Language Acquisition, University of Minnesota.

Cohen, V., \& Cowen, J. (2008). Literacy for children in an information age: Teaching reading, writing, and thinking. Belmont, CA: Thomas Higher Education.

Columba, L., Kim, C. Y., \& Moe, A. J. (2009). The power of picture books in teaching math, science, and social studies. Scottsdale, AZ: Holcomb Hathaway, Publishers.

Culham, R., \& Coutu, R. (2008). Using picture books to teaching writing with traits. New York: Scholastic, Inc.

Duke, N., \& Pearson, D. (2008). Effective practices for developing reading comprehension. Journal of education, 189(1), 107-122.

Durkin, D. (1993). Teaching them to read (6th ed.). Boston: Allyn \& Bacon.

Durkin, D. (1978). What classroom observations reveal about reading comprehension instruction. Reading Research Quarterly, 14(4), 481-533. http://dx.doi.org/10.1598/RRQ.14.4.2

Fisher, D., \& Frey, N. (2008). What Does It Take to Create Skilled Readers? Facilitating the Transfer and Application of Literacy Strategies. Voices from the Middle, 15(4), 16-22.

Fotovatian, S., \& Shokrpour, N. (2007). Comparison of the effect of reading comprehension strategies on Iranian university students' comprehension. Journal of College Reading \& Learning, 37(2), 47-63.

Frederiksen, C. H. (1972). Effects of task-induced operations on comprehension and memory processes. In R. O. Freedle, \& J. B. Carroll (Eds.), Language comprehension and the acquisition of knowledge (pp. 211-245). Washington: V. H. Winston.

Ghavamnia, M., Ketabi, S., \& Tavakoli, M. (2013). L2 reading strategies used by Iranian EFL learners: A think-aloud study. Reading Psychology, 34(1), 355-378. http://dx.doi.org/10.1080/02702711.2011.640097

Given, L. (Ed.). (2008). The SAGE encyclopedia of qualitative research methods (Vol. 2). Thousand Oaks, CA: SAGE Publications, Inc.

Goodwin, P. (Ed.). (2008). Understanding children's books: A guide for education professionals. Thousand Oaks, CA: SAGE Publications Inc.

Grabe, W. (2009). Reading in a second language: Moving from theory to practice. New York, NY: Cambridge University Press.

Harvey, S., \& Goudvis, A. (2007). Strategies that work: Teaching comprehension for understanding and engagement (2nd ed.). Portland, Maine: Stenhouse Publishers.

Harris, R., \& Pressley, M. (1991). The nature of cognitive strategy instruction: Interactive strategy construction. Exceptional Children, 57, 392-404.

Heath, C., Hindmarsh, J., \& Luff, P. (2010). Video in qualitative research: Analyzing social interaction in everyday life. Thousand Oaks, CA: SAGE Publications Ltd.

Heuvel-Panhuizen, M., Boogaard, S., \& Doig, B. (2009). Picture books stimulate the learning of Mathematics. Australian Journal of Early Childhood, 34(3), 30-39.

Hou, Y. (2013). Taiwanese EFLs' metacognitive awareness of reading strategy and reading comprehension. Lecture Notes in Computer Science, 8027, 41-49. http://dx.doi.org/10.1007/978-3-642-39454-6_5

Jalongo, M. (2004). Young children and picture books (2nd ed.). Washington, DC: National Association for the Education of Young Children. 
Janzen, J., \& Stoller, F. L. (1998). Integrating strategic reading in L2 instruction. Reading in a Foreign Language, 12(1), 251-269.

Klingner, J., Vaughn, S., \& Boardman, A. (2007). Teaching reading comprehension to students with learning difficulties. New York, NY: The Guilford Press.

Lado, A. (2012). Teaching beginner ELLs using picture books: Tellability. Thousand Oaks, CA: CROWIN SAGE.

Leu, D. J., Reinking, D., Carter, A., Castek, J., Coiro, J., Henry, L. A., Malloy, J., Robbins, K., Rogers, A., \& Zawilinski, L. (April 9, 2007). Defining online reading comprehension: Using think aloud verbal protocols to refine a preliminary model of Internet reading comprehension processes. Paper presented at The American Educational Research Association. Chicago. Retrieved from: http://docs.google.com/Doc?id=dcbjhrtq_10djqrhz

Mandler, J. M., \& Johnson, N. S. (1977). Remembrance of things parsed: Story structure and recall. Cognitive Psychology, 9(1), 111-151. http://dx.doi.org/10.1016/0010-0285(77)90006-8

Maxwell, J. (2013). Qualitative research design: An interactive approach (3rd ed.). Thousand Oaks, CA: SAGE Publications, Inc.

Merriam. S. (2009). Qualitative research: A guide to design and implementation. San Francisco, CA: John Wiley \& Sons, Inc.

Miles, M., Huberman, M., \& Saldana, J. (2014). Qualitative Data Analysis: A Methods Sourcebook (3rd ed.). Thousand Oaks, CA: SAGE Publications, Inc.

Miller, L., \& Perkins, K. (1990). ESL reading comprehension instruction. RELC Journal: A Journal of Language Teaching \& Research in Southeast Asia, 21(1), 79-94. http://dx.doi.org/10.1177/003368829002100106

Moats, L. C. (2005). Language essentials for teachers of reading and spelling, Module 6. Longmont, CO: Sopris West Educational Services.

Moore, M., \& Hall, S. (2012). Listening and reading comprehension at story time: How to build habits of the mind. Dimensions of Early Childhood, 40(2), 24-31.

National Reading Panel. (2000). Teaching children to read: An evidence-based assessment of the scientific research literature on reading and its implications for reading instruction. Washington, DC: National Institute of Child Health \& Human Development.

Ness, M. (2011). Explicit reading comprehension instruction in elementary classrooms: Teacher use of reading comprehension strategies. Journal of Research in Childhood Education, 25(1), 98-117. http://dx.doi.org/10.1080/02568543.2010.531076

Neupert, S. D., \& McDonald-Miszczak, L. (2004). Younger and older adults' delayed recall of medication instructions: The role of cognitive and metacognitive predictors. Aging, Neuropsychology, and Cognition, 11, 428-442. http://dx.doi.org/10.1080/13825580490521403

Nodelman, P., \& Reimer, M. (2003). The pleasures of children's literature (3rd ed.). Boston, MA: Allyn \& Bacon.

Oczkus, L. (2004). Super six reading strategies: 35 lessons and more for reading success. Norwood, MA: Christopher Gordon.

O’Malley, M., Chamot, A., Stewner-Manzanares, G., Kupper, L., \& Russo, R. (1985). Learning strategies used by beginning and intermediate ESL students. Language Learning, 35(1), 21-46. http://dx.doi.org/10.1111/j.1467-1770.1985.tb01013.x

Paivio, A. (1971). Imagery and verbal processes. New York: Holt, Rinehart, and Winston.

Palincsar, A. S. (1982). Improving the reading comprehension of junior high students through the reciprocal teaching of comprehension-monitoring strategies (Unpublished doctoral dissertation, University of Illinois).

Paris, S. G., Wasik, B. A., \& Turner, J. C. (1996). The development of strategic readers. In R. Barr, M. Kamil, P. Mosethal, \& D. Pearson (Eds.), Handbook of reading research (Vol. 8). London: Longman.

Pressley, M. (2006). Reading instruction that works: The case for balanced teaching (3rd ed.). New York: Guilford.

Pressley, M., \& Wharton-McDonald, R. (2006). The need for increased comprehension instruction. In M. 
Pressley (Ed.), Reading instruction that works: The case for balancing teaching (3rd ed.). New York, NY: The Guilford Press.

Pressley, M. (2002). Comprehension strategies instruction: A turn-of-the-century status report. In C. C. Block, \& M. Pressley (Eds.), Comprehension instruction: Research based best practices. New York: Guilford.

Pressley, M., Wharton-McDonald, R., Mistretta-Hampston, J. M., \& Echevarria, M. (1998). The nature of literacy instruction in ten grade 4/5 classrooms in upstate New York. Scientific Studies of Reading, 2(1), 159-194. http://dx.doi.org/10.1207/s1532799xssr0202_4

Sadoski, M., \& Paivio, A. (2013). Imagery and text (2nd ed.). New York, NY: Routledge.

Snow, C. (2002). Reading for understanding: Towards a R\&D program in reading comprehension. Washington, DC: RAND Reading Study Group.

Tovani, C. (2000). I read it, but I do not get it. Comprehension strategies for adolescent readers. Portland, Maine: Stenhouse Publishers.

Vaughn, S., Levy, S., Goleman, M., \& Bos, G. (2002). Reading instruction for students with LD and EBD: A synthesis of observation studies. The Journal of Special Education, 36(1), 2-13. http://dx.doi.org/10.1177/00224669020360010101

Williams, J. (2002). Reading comprehension strategies and teacher preparation. In A. E. Farstrup., \& S. J. Samuels (Eds.), What research has to say about reading instruction (3rd ed.). Newark, Delaware: The International Reading Association.

Yang, Y. (2006). Reading strategies or comprehension monitoring strategies? Reading Psychology, 27(4), 313-343. http://dx.doi.org/10.1080/02702710600846852

\section{Copyrights}

Copyright for this article is retained by the author(s), with first publication rights granted to the journal.

This is an open-access article distributed under the terms and conditions of the Creative Commons Attribution license (http://creativecommons.org/licenses/by/3.0/). 